これららは何れる銅碃床の風化による汪物が,その下底の殘存部, または不 灰岩に作为し，一部は更にその洞篗の一部を充たして再び沈搌したもので ある。

本研究に際してその試料を提供せられ，且つ现地の指導を辰らせる大日本碳業會

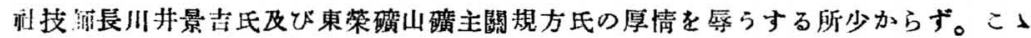

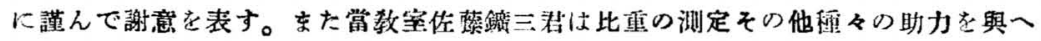
られた。こっに感謝の鲛を旺する。

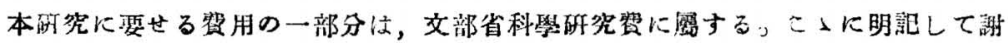
鲢に代一る。

\title{
愛媛縣岩城島産エヂル石閃長岩に就いて
}

Aegirin syenite from Iwaki I., Ehimi Pref.

理學博士 杉 健 一 (K. Sugi)

理學士 久 縌 正 典 (M. Kutuna)

I. 粕 言

II. エヂル石閃長岩の座狀

III. 岩石の壾載

a) エヂル石閃長岩

b) 石英エヂル石閃長岩

c) ペグマタイト筫及びアブラ イト澌岩石

d) エヂル石花㴊岩

e) 黑雲母花跖岩

f) リーベック解閃石プライト
IV，主構成鎮物の畄載
a) 斜長石
b) 微科長石
c) 石 英
d) 黑雲母
e) エヂル石
f) ペクトラィト
g) ニーディアル石㥞嫑物

v. 結 䓊

霄

岩城島は瀨戶队海中の一小島嶼で東西約 3.5 籸, 南北約 4.5 籸, 周圍約 I5 籸, 尾道より船便にて約一時間牛で達し得る。全島殆ビ山地で最高處は 標高 370 米ある。海岸淤近にのみ僅に平地があり,岩城村はその萠側海岸 の平地に位する。本岛の地筫に就いては既に七萬五千分の一, 尾道圖幅及 


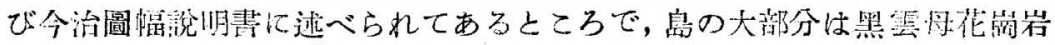

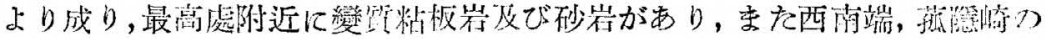

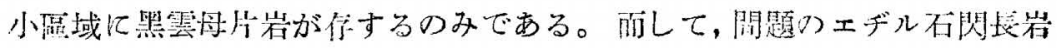

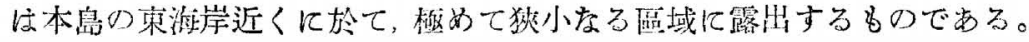
筆者の一人久綱以昭和 $I 7$ 年 $\mathrm{I} 2$ 月及び昭和 I 8 年 8 月の二国に亘り, 本岩

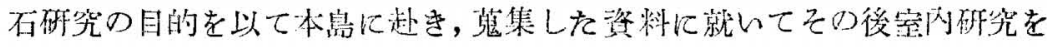

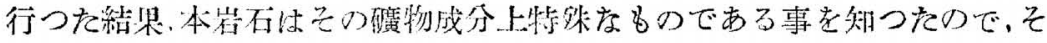

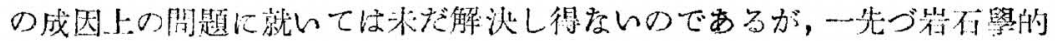

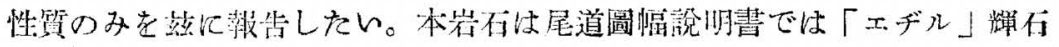

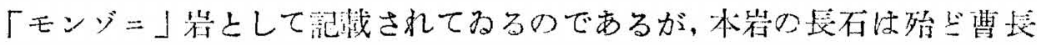

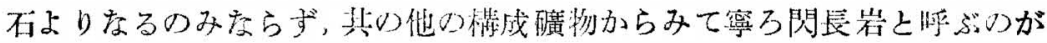

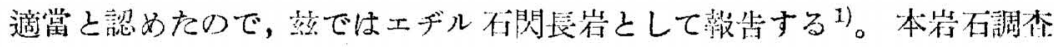

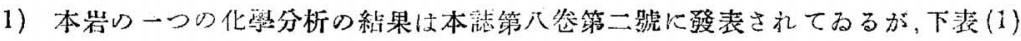

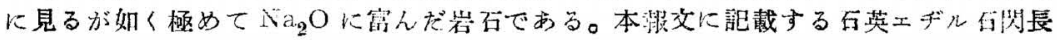

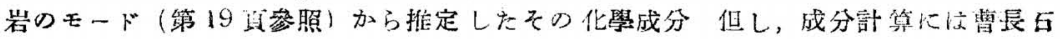
が約 10\%の Or 分子古むものとして, 即ち $\mathrm{Or}_{10} \mathrm{Ab}_{86} \mathrm{An}_{4}$ として之を行つた。) を

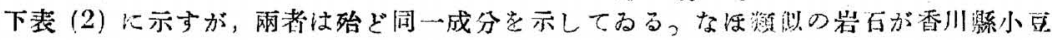
島池田附近及ど大阪府二上山西南㕠附近に㡾すること洨周知の通りである。

(1)

68.44

0.05

17.68

1.04

1.00

0.07

0.40

0.97

8.53

1.94

$\mathrm{K}_{2} \mathrm{O}$

$\mathrm{P}_{2} \mathrm{O}_{5}$

Ig. loss
0.1

17.9

1.6

0.1

0.0

0.2

1.1

9.7

1.7

tr

Total 100.12<smiles>COCCO</smiles>

$\begin{array}{rrr}\text { Ig. loss } & \cdots \cdots & \left(\mathrm{H}_{2} \mathrm{O}\right) \\ 0.0\end{array}$

（1）北大，金成明氏分析以上当本岩の化學成分。

(2) 䂟成息石英エデル石闪長岩の推定化學成分。 
に際し,種及便宜を與へられを岩战村役場の各位に對し,厚く感謝する。ま た本研究に要した費用の一部に文部少科學研究費を用ひた。茲に明記して 深謝の意を表する。

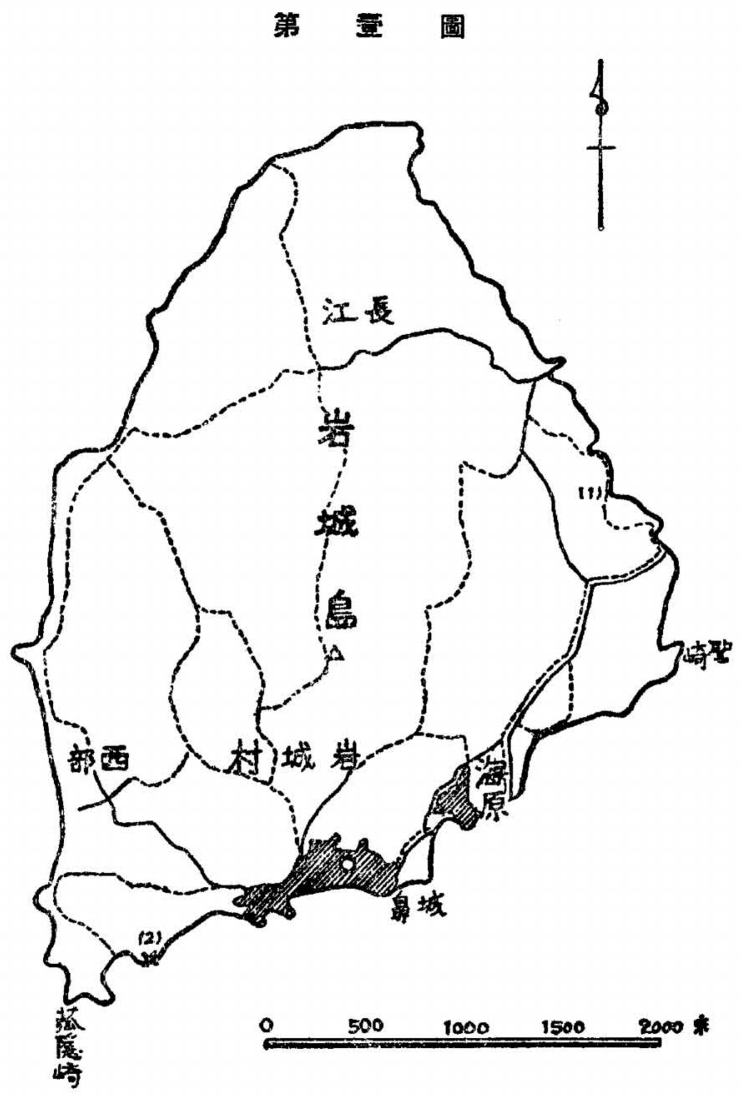

岩城皇 略圖

(1) エヂル石閃長岩の露出箇所

(2) リーペツク角閃石アブライトの露旪筒所

\section{II. エヂル石閃長岩の産狀}

前述せる如く，本岩の露出简所は極めて小區域であつて，全體から判斷す ると小さな岩株狀の岩體をなして花溯岩中に鿓入してねるものと考へられ 
ろ。本島東游岸近くの道路に沿ふてその好露出がある。肉腿的に㯵青灰白

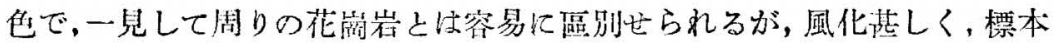
を得るには不適である。然し此䶮から西方の峰に上ると幸に探石場があつ て, 新䑾な資料が得られる。またこの峰より西へ急峨な斷崖を下れば約十 米にして花丽岩との接䪅部がある。但し网者以劃然をる面を以て境せず，

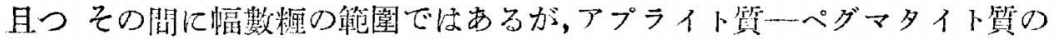

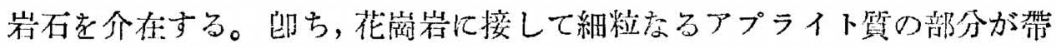

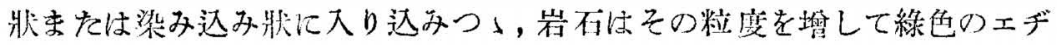
ル石を含む粗粒なるペグマタイト筫となり，更に石英を含む閃髟岩質の部 分を經て木體たるエヂル石閃長岩となる。

\section{III. 岩 石の記 載}

\section{a) エヂル石閃畏岩}

白色粗粒の岩石で,長石の䢃開面は脂肪光溜を呈し,濃綠色のエヂル石の 集合部之共に橄欖色の部分及び稍々褐色を带びをる灰色の部分を含んでる る。ての部分を取り出して顯微鏡にて檢せし結果, 橄欖色の部分は主に二 ーディアル石梯礦物よりなり，裀灰色の部分はペクトライトである事が分 つた。エヂル石の含有量は非常に不均一であり多き部分は $27 \%$ (容積比) に達し,少き部分では㱠ざ之を缺く。主成分は曹長石, エヂル石, ペクトラ イト、ニーディアル石樣硔物であり，副成分は斜黝䈨石，燐灰石等である。 代表的岩石に於ける構成礦物の割合は第壹表の如くである。なほこの外に 僅に石英を含むことがある。

\begin{tabular}{|c|c|}
\hline 曹長 石 & $87.0 \%$ \\
\hline エヂル石 & 4.0 \\
\hline ペクトライト & 2.3 \\
\hline ニーディアル吕淾研物 & 6.6 \\
\hline 斜黟籍石 & 0.2 \\
\hline
\end{tabular}


曹長石 ${ }^{1)}$ は概权本自形をなし, 規則正しを縞狀のアルバイト双晶をなす ものと、不規則な縞狀の双晶ををするのとあり,大きな結晶は長さ $3 \cdot 5 \sim 5$ 粔に達し，累帶構造は示さ古い。この外更に徑約 0.2 粍位の粒狀の小晶が 集合的に，或は間吵充塂的に存在してるる。エヂル石は深綠色乃至黃綠色 在呈し, 大きさ $0.2 \sim 0.3$ 䊗の響狀の結晶で ペクマトイト及びューディア ル石樣黉物之共に密集し, 或はまた間乿立墴的に为存在してるる。ペクト ライトは無色,等開完全で複属折高く，一見白答母の如く見える。大ささは I.O〜I.5 籷に達するものあり, 自形乃至本自形をなす。ーデイアル石稼

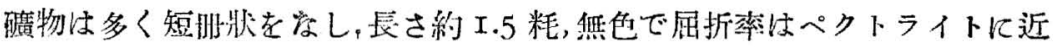
いが 複屈折㥛めて低い。伸での性質は正でそれに直角に(底面に平行 か?)䢃閉があり黃綠色の微細なる蔍状物質を多く含んでねる。

\section{b) 石英エヂル石閉長岩}

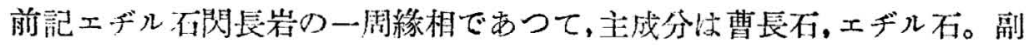
成分は石英 微科長石, 燐灰石等で構成磺物の割合は第二表の通りである。

\section{第式表}

\begin{tabular}{|c|c|}
\hline 英 & $4.2 \%$ \\
\hline 曹 辰 石 & 87.9 \\
\hline 微斜長吕 & 1.0 \\
\hline エデル石 & 6.9 \\
\hline 區 雲 母 & 0.1 \\
\hline
\end{tabular}

曹長石の形狀には前項のエヂル不閃長岩の場合と同じく規則正しき縞狀 のアルバイト双晶をなすものと不規則なる滴狀の双晶をなすものと 粒狀 のものと三通りの型がある。エヂル石の大きさ、裔狀もェヂル石閃長岩の 場合上同樣である。微斜長石は他形をなし 其の量極めて少く, 石英も間嘹

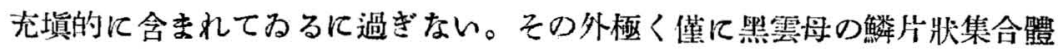
を含んでるる。

c）ペグマタイト㨁及びアプライト筧岩石

1）多少の加里畏石分（恐らく $10 \%$ 内外）を会むであら5。第 16 頁脚諘參照。 
何れも閃長岩の外側をなす岩石で閃长岩に近き部分はぺグマタイト筫， 花崗岩に近き部分はアプライト質となつてるる。ペグマタイト質の部分は

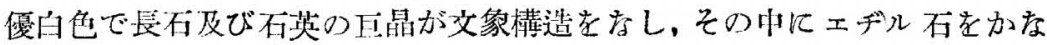
り多く含んでねる。アプライト質の部分は優白色, 細粒で花㴊岩中に脈狀 に染み込んでるる部分もあり,やはりエヂル石を含む。主成分は微斜長石， 曹長石, 石英で, 副成分はェヂル石その他である。微斜悵石，曹長石，石英等 は所謂寄木細工状をなしその闑償に粒狀のエヂル不が集合してねる。曹 長石はアルバィト双晶をなし，大部分は累帶構造を示さないが，稀に之を 示するのがある。以上の礦物の外に少量の品雲日の鱗片集合體を含んでる る。

\section{d) エヂル石花崗岩}

岩城島花厥岩の中, 上記閃長岩類との接觸部に近し部分には黑雲母の外 にエデル石が含まれてるるととい，斜長不が曹長石から成るととを特徵と する。本岩は白色の長石，牛透明の石英及び黑色金風光澤老有する黑雲母 よりなる粗粒の岩石で、エヂル不の集合部は濃綠色を呈する。構成碃物の 割合は第三表の如くであり，石英及び微斜長石を多量に含んでるる。

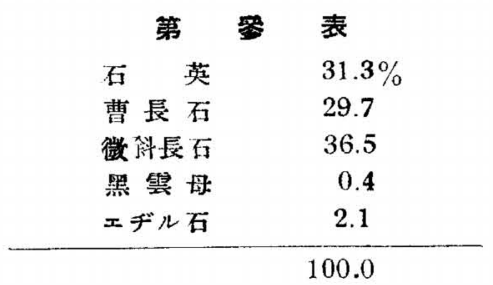

主成分は微斜長石, 曹長石, 石英, エヂル石, 黑雲母で, 副成分は棤石, 鐵磧 類である。微斜長石は所謂微斜長石構造をなし、又ペルト石構造をなして わる。曹長石（其の大部分がより基性の斜長石の曹長石化作用を受けをる

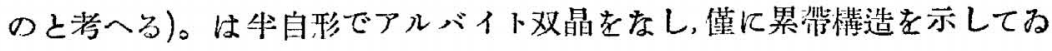
る。エヂル石は曹長石の細粒結晶と共に粒状集合體をなして散在し，又黙 雲母は牛自形をなしその量も少い。鐵磺類はエヂル石と共存し赤鐵磺に屬 
するものと思はれる。

\section{e) 黑雲舟花蓠岩}

本島を構成する主要なる岩石で, 本島最高處附近を除く大部分に露出す るも，一般に風化著しく糜擱してるる。帶紅色の加里長石，白色の斜長石， 牛透朋の石英及び板狀金阙光澤を有する黑褐色の黑雲母よりなる粗粓の岩 石で,エヂル 石は含有してをらない。主成分は微斜長石，斜長石，石英及び 黑雲母で, 副成分は鐵磺類 (磁鐵磺及び赤鐵磺), 白雲母, 燐灰石, ヂルコン, 褐笼石等である。構成礦物の割合は第四表の通りである。

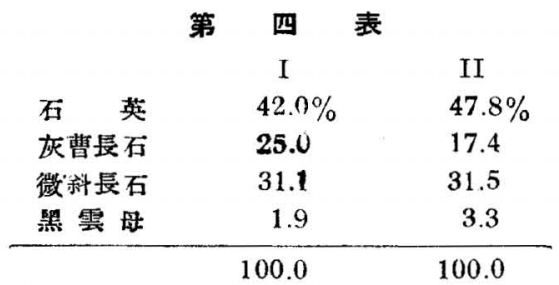

微斜長石は微斜長石構造を示し 科長石はアルバイト双晶及びペリクリ ン双晶をなして累帶構造を示するのあり，その成分は核心部は灰曹長石で 外圍部は曹長石である。概坟牛自形をなす。石英は他形ををしその量約 $45 \%$ 几澾する。黑㹃母は自形乃至本自形をなして锞集し，多色性顯著で $\mathrm{X}=$ 淡黃褐乃至黃褐色。 $\mathrm{Y} \doteqdot \mathrm{Z}=$ 濃褐乃至暗褐色である。鐵礦類は黑雲

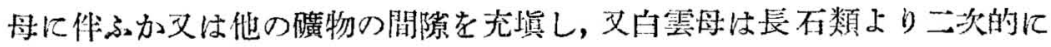
生成されをものである。燐灰石，ヂルコン等は微晶をなして黑县母中几包 裹せられ, ヂルコンの周图には多色性最が見られる。な后㫮雲母及び長石 類の變成物として綠泥石, 綠簾石，白チタン石等古含むものがあり，か小る ものでは斜長石も曹長不化作为を受けてるる。

\section{f) リーペック角閉石アプライト}

黑雲母花崗岩を貫く脈岩である。や小暗色を呈する中粒㮹密なる岩石 で, 有色䃓物として黑雲母の外に濃綠色のリーベツク角閃石を含んでるる。 主成分は微斜長石，斜長石，石英で㣂成分は黑雲母,リーベツク们閃石，ヂル 


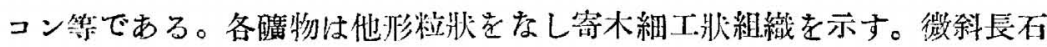

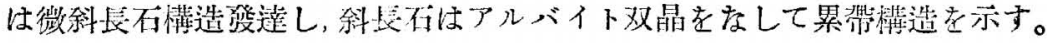

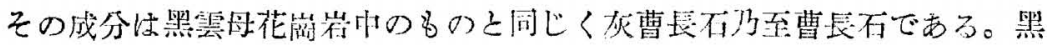

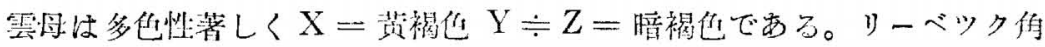
閃石多多色监著しく $X=$ 濃青綠色 $Y=$ 淡褐黃色 $Z=$ 睹綠色である。

\section{III. 主構成礦物の記載}

\section{a) 斜長石}

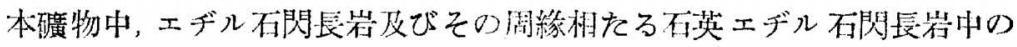

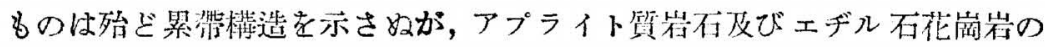

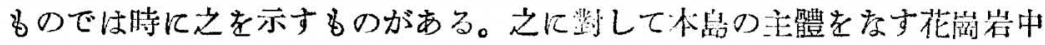

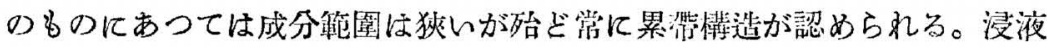
法により屈折率を測定した結果は第五表に示す如く, エヂル石閃㔫岩, 石英 エヂル石閃長岩，アプライト質岩石及びェヂル石花峝岩中のものは殆ど同 一值を示し， $\alpha=\mathrm{I} .529 \gamma=\mathrm{I} .539 \gamma-\alpha=0.0$ IO であつて曹長石 (An5)に

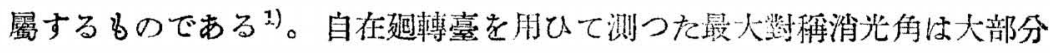

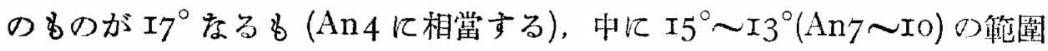
のものがあつた。エヂル不花搠岩中のものは曹长们化作朋を受けた結果，

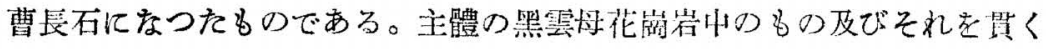
リーベツク角閃石アプライト中のものでは, その屈折率 $\left(\alpha=\mathrm{I} .53^{8} \gamma=\right.$ I.545 $\gamma-\alpha=0.007$ ) からみると灰曹辰石 (An I 8) であるが, 最大龂稳消光 刍它測定した結果は核心部は $6^{\circ}$ (An I8)，外圍部は I4 (An 9) を示した。

閃長岩類の曹長石つ顯微鏡下に於ける形状に三つの型があることは䅋に 述べた。其の一は最も普通なアルパイト双品をなするので, 直交ニコルの 下で平行な明暗の縞を表するのである。其の二は断版的なアルバィト双晶 をなす結晶片が平行に奇り集つたかの如を觀を呈するもので,符一のるの とは大んに異るや5に見えるが、㐋を直交ニコル間で趩轉して調へると, 絬

1) 但し，多少の Or 分子を会むものであら5。第 16 頁脚註誉照。 
局通労のアルバイト双晶と同一のものであつて，接合面が较く續かず双晶 が断片的であるためである(第式圖)。特にペグマタイト篟岩不中の大をる

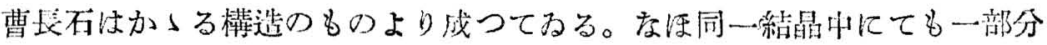

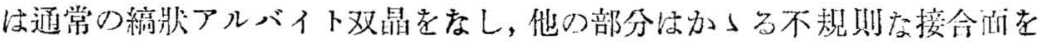

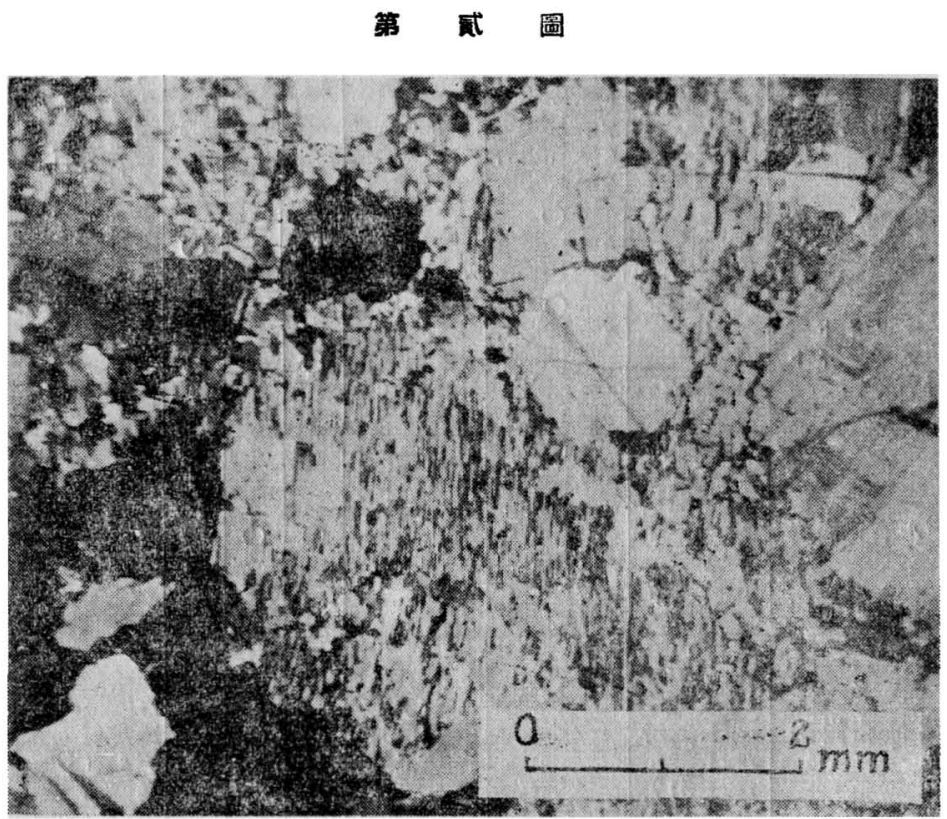

不規則なるアルバイト双晶をなす曹長石

示すアルバイト双晶ををするのもある。其の三は小なる粒㹜をなしてェヂ ル不ペクトライトニニーデイアル石椂磺物之共に mortar structure を产 して存在するものである。かくの如く外觀は異るが三者共にその屈折率に は奎異がをく,從つて同一成分の曹長石である。

\section{b) 微斜長石}

本磺物はエヂル石閃長岩には含まれず，その周緗相をる石英エヂル石閃 壾岩,アプライト質岩石，エヂル石花崗岩の頙を追つて其の量を增し，黑雲 
母花峝岩及びそれを貫くリーペツク角閃石アプライト中には最も多量に存 する。顯微鏡下に一般に著しく濁つてみて，何れも微科長不構造を示す。 浸液法にて測定せる屈折率は第五表に示す如くであり，各岩種を通じて何 第 五 表 各程岩石の構成䃓物亚儿長石の屈折率を示す表

\begin{tabular}{|c|c|c|c|c|c|c|c|}
\hline & 微斜長石 & 曹長 石 & 灰曹長石 & 石英 & 黑零 & $\begin{array}{l}\text { エヂ } \\
\text { ル石 }\end{array}$ & その他の隨伴䃓物 \\
\hline エデル石閃長岩 & - & $\begin{array}{l}0 \\
a=1.528 \\
\gamma=1.539 \\
a=1.531 \\
\gamma=1.539\end{array}$ & & - & 一 & 0 & 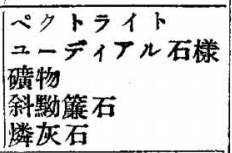 \\
\hline $\begin{array}{l}\text { 石英 エヂル石 } \\
\text { 閃 長 岩 }\end{array}$ & $\beta=\bigcirc_{1.525}$ & $\begin{array}{c}\mathrm{O} \\
a=1.530 \\
\gamma=1538\end{array}$ & & 0 & - & 0 & 橉灰石 \\
\hline $\begin{array}{l}\text { ペグマタイト質 } \\
\text { 及びアプライト } \\
\text { 堅岩石 }\end{array}$ & $\begin{array}{c}0 \\
a=1.519 \\
\gamma=1.526\end{array}$ & $\begin{array}{l}\quad 0 \\
a=1.529 \\
\gamma=1.539 \\
a=1.529 \\
\gamma=1.539\end{array}$ & & 0 & - & 0 & \\
\hline エヂル石花崗岩 & $\begin{array}{c}0 \\
a=1.519 \\
\gamma=1.524 \\
a=1.518 \\
y=1.525\end{array}$ & $\begin{array}{c}0 \\
a=1.531, \\
\gamma=1.540 \\
a=1.531 \\
\gamma=1.539 \\
a=1.530 \\
\gamma=1538\end{array}$ & & 0 & 0 & 0 & 桶石 \\
\hline 黑雲母花崗岩 & $\begin{array}{l}0 \\
a=1.518 \\
\gamma=1.526 \\
a=1.520 ? \\
\gamma=1.525 \\
a=1.517 \\
\gamma=1.525\end{array}$ & & $\begin{array}{c}0 \\
\alpha=1.538, \\
\gamma=1.545\end{array}$ & 0 & 0 & - & 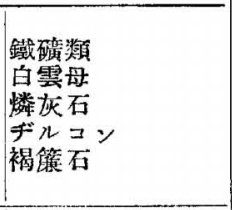 \\
\hline $\begin{array}{c}\text { yーペック角閃石 } \\
\text { アプライト }\end{array}$ & $\begin{array}{l}0 \\
\alpha=1.521 ? \\
y=1.525\end{array}$ & & $\begin{array}{c}0 \\
a=1.538, \\
\gamma=1.544\end{array}$ & 0 & $\mathrm{O}$ & - & $\begin{array}{l}\text { リーベック觕聞石 } \\
\text { ヂルコン }\end{array}$ \\
\hline
\end{tabular}
一印文不在老意味す。

れも殆ど $\alpha=1.518 \gamma=\mathrm{I} .525 \gamma-\alpha=0.007$ であつて, またいづれも光軸 角が大 (光學性：負)である。殆ど純粹なる加里長石と認められタが, 結晶 中にはぺルト不構造をなして曹辰不定包含する故, 全體としての成分沬多 少の曹長不分を含むものである。

\section{c) 石 英}

エヂル石閃辰岩には殆ど含まれず，石英エヂル石閃長岩アアプライト質岩 


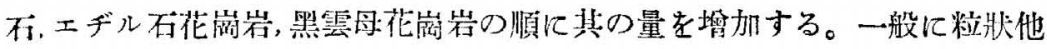
形をなして存在する。

\section{d) 黑 雲}

エヂル石閃長岩，石英エヂル不閃長岩，アプライト質岩石中には之を缺

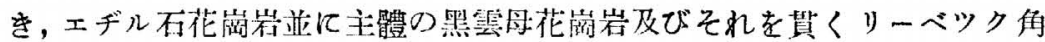
閃石アプライト中の成分として存する。但し其の量は少い。多色性著しく

$\mathrm{X}=$ 褐率乃至綠褐色 $\mathrm{Y} \doteqdot \mathrm{Z}=$ 不透朋に近々暗褐色で, 自形乃至牛自形 結晶をなす。

\section{e) エヂル石}

エヂル石閃长岩, 石英エヂル石閃長岩,アプライト質岩石, エヂル石花崗

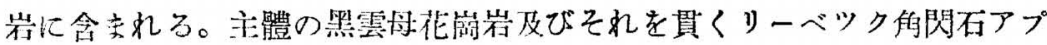
ライト中には倞在しない。徑 0.2 〜 0.3 粍拉の粒狀の結晶で, 他の磺物, 例

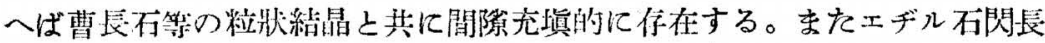
㞸に於ては，その外ペクトライトニーディアル石樣砝物と密接に伴つて举

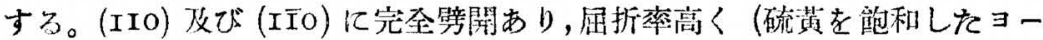
ドメチレン液の屈折率上り䯩い), 光軸角は $2 \mathrm{~V}($ ( $)=67.5^{\circ}$ 消光角 $\mathrm{X} \wedge \mathrm{C}$

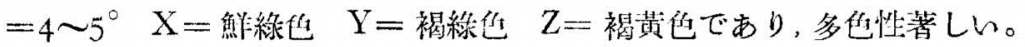

\section{f) ペクトライト}

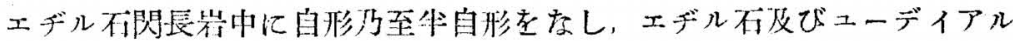

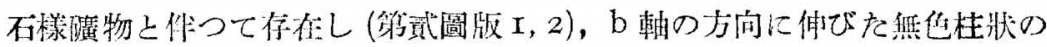
結晶で，(IOO) 及び (OOI) ル等開完全で管開面閆の角は略々 90である。 $\mathrm{b}=\mathrm{z}$ で伸長の性質は正，光軸面上(OIO) である。b軸沉垂渲なる薄片では 殆に゙直伆に交る二方向に䢃閉があつて複屈折低く， $\mathrm{b}$ 軸に平行なる薄片で

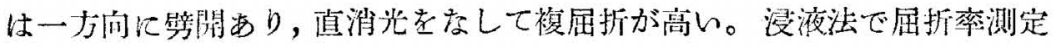

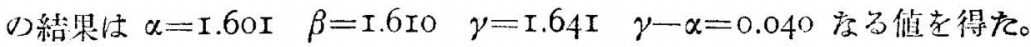
また自在䢙榑索にて光軸的老测定した絬果は $2 V\left(\right.$ ( $=50 \sim 55^{\circ}$ を示す。

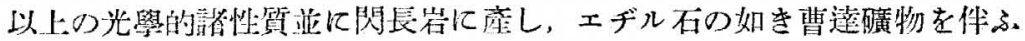


等の産狀よりペクトライトなることを知る。本磺物については先に原田敎

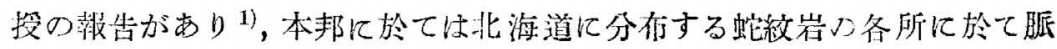

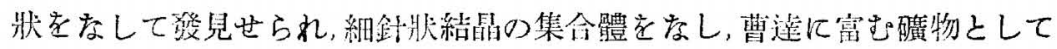

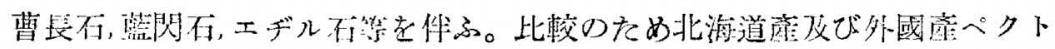
ライトの光學的性質を表示してみる之第六表の遖りである。

第 六 表

\begin{tabular}{|c|c|c|c|c|c|c|}
\hline & $a$ & $\beta$ & $\gamma$ & $\gamma-a$ & $2 \mathrm{~V}$ & 光學性 \\
\hline I. 北海道雨能潼 & 1.594 & 1.603 & 1.631 & 0.037 & $59^{\circ} 57^{\prime}$ (棓䉪) & $(+)$ \\
\hline II. 闰 占冠漟 & 1.594 & 1.605 & 1.632 & 0.038 & $64^{\circ} 50^{\prime}$ (同) & $(+)$ \\
\hline 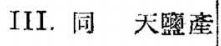 & 1.595 & 1.604 & 1.633 & 0.038 & $60^{\circ} 1^{\prime}$ (同) & $(+)$ \\
\hline $\begin{array}{c}\text { IV. 北米 Bergen } \\
\text { Hill 産 }\end{array}$ & 1.595 & 1.606 & 1.633 & 0.038 & medium large & $(+)$ \\
\hline V.ロシアKola 潼 & 1.610 & $1.642(?)$ & 1.643 & 0.033 & $53^{\circ}$ & $(+)(?)$ \\
\hline VI. 岩城岛㡾 & 1.601 & 1.610 & 1.641 & 0.040 & $50^{\circ} \sim 55^{\circ}$ & $(+)$ \\
\hline
\end{tabular}

I.-III. 本誌第八参第六號 253 頁. IV. E. S. Larsen : The microscopic determination of the nonopaque minerals 1921, p. 118 . V. American Mineralogist Vol. 11. 1926, p. 298.

\section{g) ユーディアル石㧼磄物}

エヂル石閃長岩中にエヂル石及びペクトライトと伴つて存在し, 鏡下に

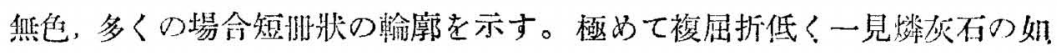
く見えるが，伸長の性質が正なる點が之と相異する。伸びに谊的に䲞開あ

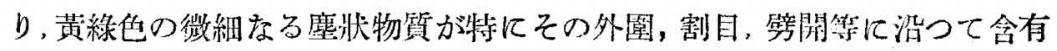
せられる。浸液法により屈折率を测定せる結果 $\omega=\mathrm{I}$.6IO $\varepsilon=\mathrm{I} .607 \omega-$ $\varepsilon=0.003$ を得た。干涉像が不鮮明であつて(厚い薄片にても明膫でない),

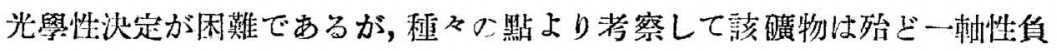
結晶, 又は殆ど等方體であり，伸長の方向に淔角に光軸があつて，その方位 はXである。エヂル石閃長岩中には該磺物の他に燐灰石及び斜䵢簏不が 含有せられるが，該礦物は燐灰石之は伸长の性筫が異る外，必ず黄綠色の鷹

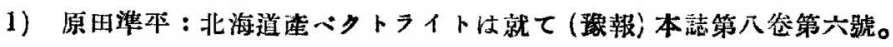


第鉒圖

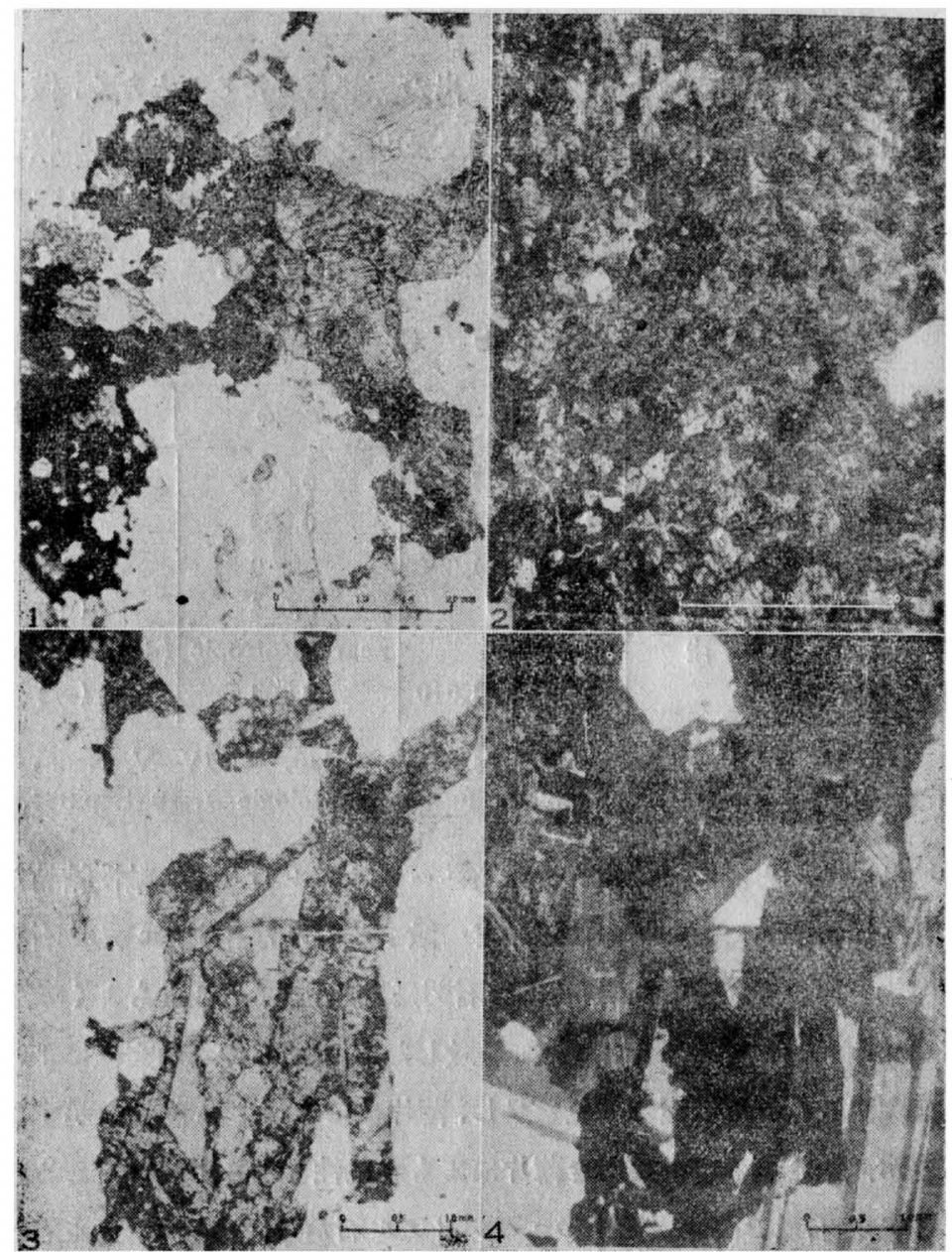

左上ペクトライト及びェヂル石の集合部（灰色の部：ベクライト 暗墨 部：エヂル石 白色部:曹長吕) 本行二コル $\times 19$

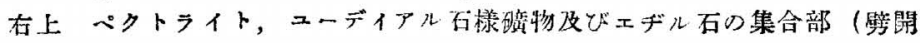
の見られる稍々日き部：ベクトライト灰色の部：ニーディアル石

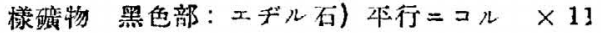

左下ニーディアル石樣溃物（灰色の部。他は曹長石）本行ニコル 右下 同上十字 $=\geq ル \times 9$ 


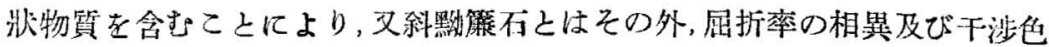
の違ひによつて區別せられる。

本磺物は未だ本邦內地よりはその産出の報ぜられたるととなく，僅に朝 鮮福辰山のへスチングス解閃石霞石閃長岩中に含有せられることが報ぜら れてるるが1)，光學的性質その他の資料は記载されてをらなん。外國產の ものと光學的性質を比較してみると，第七表の如くなる。

第 $\quad$ 表

\begin{tabular}{|c|c|c|c|c|}
\hline & $\varepsilon$ & $\omega$ & $\varepsilon \sim \omega$ & 光 學 性 \\
\hline I. Greenland 㽓 & 1.610 & 1.608 & 0.002 & $(+)$ \\
\hline II. Umptek, Kola 產 & 1.613 & 1.610 & 0.003 & $(+)$ \\
\hline III. Lujaur Mt., Kola 珄 & 1.606 & 1.606 & 0 & $(+)$ \\
\hline IV. Angvundascorr, Kola 漟 & \multirow{2}{*}{\multicolumn{2}{|c|}{$\begin{array}{l}1.593 \\
1.604\end{array}$}} & 0.004 & $(+)$ \\
\hline V. Ljawajoka, Kola 莝 & & & nearly isotropic & $(+)$ (Mesodialite) \\
\hline VI. 岩城島产 & 1.607 & 1.610 & 0.003 & $(-)$ \\
\hline
\end{tabular}

I-III. J. P. Iddings: Rock Minerals. 1911, p. $440 . \quad$ IV-V. Neues Jahrbuch für Mineralogie, Geologie und Paläontologie. I. 1931, p.364.

岩城島裳䤑物と既に記載されてねるユーデイアル石とは一軸性結晶なる てと及び座折率並に複屈折の值が多台ど一致するのみならず, エヂル 石等の 曹達磺物を伐つてアルカリ岩(特に霞石門長岩)に髉することもよく一致す ろが闪腿的の色及び光學性に於て一致しない。郎ち從來の文㱆によれば 多くは肉眼的に紶色乃至赫紫を呈し, 薄片にても僅に多色性を示すこと

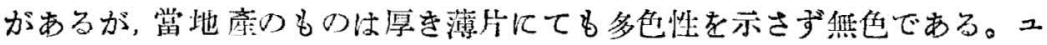
ーディアル 石䐂では光學性正のューディアル石から,負のニーコル石へ潮 移する(その中間の㱠ど等少體のものを mesodialite と呼ぶ ${ }^{2)}$ ) ものであ る。本硔物は光學性負なる點に於てはむしろューコル石之一致するが, 届

1) 吉澤 甫：朝鮮福辰山㡾へースチンダ石に就いて。(地球第 26 突第 2 號)

2) A.E. Fersman : Minerals of the Kola Peninsula. (American Mineralogist Vol. 11, 1926, p. 289) 參照。 
折率がユーデイアル石に近似するので，玆ではユーデイアル石橙礦物とし てをくことにした。該矌物を取り出して分析し，その化學成分を磼めるこ とが望ましいが, 不純物を多く含有するため純粹るる资料を得ることが極 めて困蜼であると思心れる。

\section{V. 結眖}

岩城島エヂル石閃倀岩は墨雲母花崗岩を鿓く小岩株狀岩體をなするの上 考へられ，曹長石，エヂル石，ペクトライトニーデイアル不橙䤑物等の含曹 迲舼物類を以て特徽付けられてるる岩不であるが,か小るアルカリ岩がそ の風緣部江石英を含むアプライト貿及びペグマタイト質岩石を有するて と，まを别にリーベツク伤閃石の如きアルカリ㘬閃石を含むアプライトが 同樣に熙雲母花崗岩を鿓いて産出することは興味あることであつて, 閒題 のアルカリ㞸が花溯岩賢アプライトヌはペグマタイトと密接を關係にある 岩石をることを示してねるものと思はれる。エデル石閃辰岩の構成磏物よ

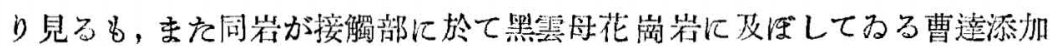
の現疑(花崗岩の科長石の曹長石化作用及びェヂル石の生成等) から見るも， 該閃長岩文漿が極めて曹達に舜んでるたるのと考へられるが，それと共に 石英分を缺くことが如何なる原因によるものであるかは，岩不學上極めて 興味ある問題であると共に，また解沃に困難なる問題でもある。石灰筫岩 石等による脫珪酸作用を示すが如き徽候の有焦に就いては，特に注意した のであるが1)，之れに對しては樍極的な手掛りが得られなかつね。 R.C. Emmons は花崗岩質岩漿が結晶作用の途上, 分別聇を受けを場合に, 極め て石英分にとめる殘液が逸出することにより，閃舆岩犋岩不の生成を考入 でる2。若し此の際，曹達分に比して多量の加里分取り去られるなら

1) P. Eskola: On the Igneous Rocks of Sviatoy Noss in Transbaikalia (Översikt av Finska Vetenskaps-Societetens Förhandlingar. Bd. LXIII. 1920 -1921. Afd. A. No. 1).

2) R.C. Emmons: The contribution of differential pressures to magmatic differentiation. (American Journal of Science Vol. 238, 1940 p. 13) 


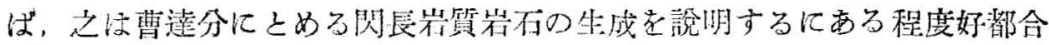

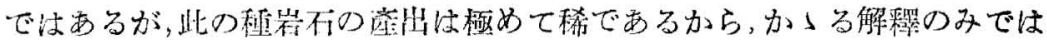
滿足することが出來度い。現在筆者等は之の生因に關して滿足な說明をな し得ないので,之を將來の閒題として殘すととつし，本報文ではその特異な

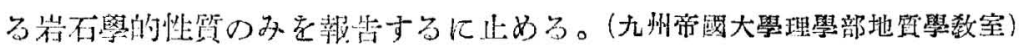

\title{
鏡 檢 分析 の 實 驗 $(\mathrm{V})$
}

\author{
$\mathrm{Al}, \mathrm{Sn}, \mathrm{Pb}, \mathrm{P}, \mathrm{As}, \mathrm{Sb}$ の鏡檢分析 \\ Some experiments on microchemial analyses (V) \\ Microchemical analyses of $\mathrm{Al}, \mathrm{Sn}, \mathrm{Pb}, \mathrm{P}, \mathrm{As}$ and $\mathrm{Sb}$
}

理學士 須 藤 俊 男 (T. Sudô)

アルミニゥム ${ }^{1)}(\mathbf{A} 1)$

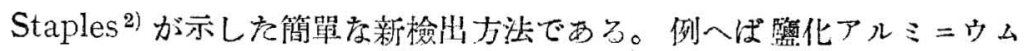
の溶液を蒸荻乾固し, 乾固膜の上にモリブデン酸アムモニウムの飽和溶液

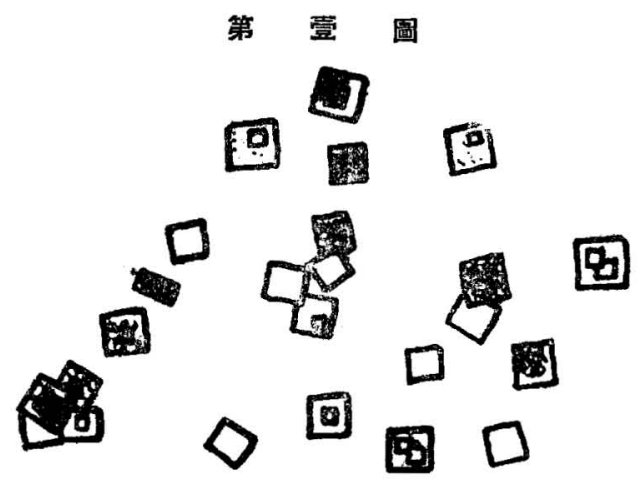

モりブデン酸フムモニゥムによるアルミニゥムの反應 $(\times 75)$

を加へると，第鳌圖に示した栐な無色のほとんど正方形に近い菱形板状の

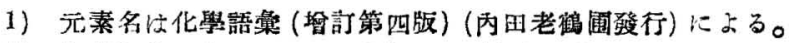

2) L.W. Staples: Amer. Miner., 21 (1936), 613. 